\title{
Pomnikowe dzieła regionalizmu polskiego
} Monumental works of Polish regionalism

Streszczenie. Regionalizm jest ruchem społecznym zmierzającym do podtrzymania i rozwoju osobliwych i najbardziej typowych cech gospodarki i kultury poszczególnych obszarów naszego kraju. Realizuje się on w sferze gospodarczej, kulturowej (zwłaszcza artystycznej), oświatowej i naukowej. W artykule szczególną uwagę poświęcono regionalizmowi w nauce, prezentując badania oraz dzieła, których treścią są zjawiska poszczególnych regionów. Ze względu na objętość, zawartość - a co za tym idzie - i na ważność tych dzieł nazywamy je „pomnikowymi”. Należą do nich: bibliografie regionalne, monografie i encyklopedie regionów i miejscowości, regionalne i lokalne słowniki biograficzne zawierające życiorysy osób zasłużonych, albumy, a także literatura traktująca o lokalnych nekropoliach. Twórcami tych, niejednokrotnie monumentalnych, dzieł są miłośnicy poszczególnych regionów i miejscowości, pasjonaci badań regionalnych, pracujący żmudnie, niekiedy przez wiele lat, w pojedynkę bądź zespołowo. Ich dzieła nie tylko przypomniały i utrwaliły dzieje poszczególnych regionów, miejscowości i żyjących tam ludzi, chroniąc to wszystko od zapomnienia. Te okazałe, niejednokrotnie wielotomowe publikacje to dzisiaj forma utrwalania regionalnej i lokalnej tożsamości ludzi. To także niezgłębione źródło treści kształcących i wychowawczych dla uczącej się młodzieży szkolnej i kształcących się dorosłych.

Słowa kluczowe: regionalizm, bibliografie regionalne, encyklopedie, monografie regionów i miejscowości, lokalne słowniki.

Summary. Regionalism is a social movement aiming at maintaining and developing exceptional and most typical characteristics of the economy and culture of our country's individual regions. It can be realized in the spheres of economy, culture (art in particular), public education, humanities and social sciences. This paper focuses on the regionalism in social sciences by presenting the results of research and works dedicated to individual regions. On account of presence of extensive size, content and importance of works they 
are referred to as "monuments." These include regional bibliographies, monographs, encyclopedias of regions and towns, regional and local biographic dictionaries with entries referring to people of outstanding merit, albums and literature devoted to local necropolises. Authors of these monumental works are considered to be the adorers of individual regions and towns as well as enthusiasts of regional researches who are working arduously for many years either alone, or as a team. Their works reminded and preserved the history of regions, towns and their inhabitants thereby protecting them from being forgotten. Today, these voluminous publications help to preserve regional and local identity. What is more, these are very valuable educational materials both for youths and adults continuing their education.

Keywords: regionalism, regional bibliographies, encyclopedias, monographs of regions and towns, local dictionaries.

Regionalizm jest ruchem zmierzającym do podtrzymania i rozwoju specyficznych cech gospodarki i kultury poszczególnych obszarów naszego kraju. Realizuje się on w sferze gospodarczej, artystycznej, oświatowej i naukowej. W sferze gospodarczej wyraża się w uprawie specyficznych dla danego regionu roślin oraz produkcji specyficznych wyrobów (sprzęt gospodarstwa domowego, narzędzia, meble ogrodowe, potrawy, zabawki) najczęściej w miejscowych surowców i z zastosowaniem technologii wypracowanej w danym regionie. Przykłady, by ograniczyć się tylko do Małopolski, stanowią miejscowości nad Dunajcem w rejonie Czchowa i Zakliczyna, specjalizujące się w uprawie plennej odmiany grochu o nazwie „Piękny Jasiek” i produkcji $\mathrm{z}$ niego prawie setki potraw (ze smaczną kiełbasą włącznie). Dostarcza go także Ziemia Miechowska, a konkretnie rejon gminy Charsznica uchodzącej za zagłębie uprawy kapusty i sporej liczby produkowanych z niej potraw. Większości Polaków znane są regionalne produkty spożywcze z Podhala i rejonu Tatr, a także serwowane potrawy regionalne w tamtejszych barach i restauracjach. Do regionalnego należy poszukiwany napój produkowany ze śliwek w Łącku i okolicy. W skali kraju ruch ten stymuluje Polska Unia Produktu Regionalnego i Lokalnego (obecnie rejestruje w swoim wykazie 37 produktów). Coraz częściej powstają też regionalne struktury gospodarcze, np. na Podlasiu Zrzeszenie Produktów Sera Korycińskiego.

Znane też są w naszym kraju miejscowości wyspecjalizowane w produkcji stolarki okiennej, odzieży regionalnej i obuwia, dobrych mebli i poszukiwanych narzędzi pracy. Te produkty stały się szansą dla rozwoju gospodarczego, a niekiedy i poprawy atrakcyjności turystycznej wymienionych rejonów. Do regionalnej i lokalnej tradycji gospodarczej poszczególnych regionów (surowce, warunki geograficzne, doświadczenia wytwórcze) nawią- 
zują dzisiaj intensywnie rozwijające się agencje rozwoju regionalnego. Przykładem mogą być: Jurajska Izba Gospodarcza, Tarnowska Agencja Rozwoju Regionalnego czy Mielecka Agencja Rozwoju Regionalnego wspierające rozwój swoich regionów przez wykorzystanie istniejącej w nich specyfiki i osobliwości geograficzno-gospodarczych.

Regionalizm w sferze artystycznej to głównie nawiązywanie do chłopskiej sztuki ludowej (architektura, zdobnictwo w drewnie i żelazie, ceramika, rzeźba, malarstwo, tkanina i in.) oraz reaktywowanie reliktów folkloru (literatura, muzyka, strój ludowy, obrzędowość i in.). Pod tym względem występuje w naszym kraju, podobnie jak i w innych państwach, daleko idąca regionalizacja (Węglarz, 1997). Dorobek artystyczny i kulturowy regionów jest dzisiaj przechowywany w muzeach etnograficznych (na wolnym powietrzu) (Sieraczkiewicz, Święch, 1999) oraz w izbach regionalnych, zaś bogaty folklor demonstruje się m.in. na uroczystościach narodowych, religijnych, obrzędowości świątecznej, specjalnych imprezach artystycznych, a także zgromadzeniach publicznych i zabawach ludowych, w środkach masowego przekazu oraz na nagraniach elektronicznych i w wydawnictwach drukowanych (Brzezińska, Tuchonowicz, 2013).

Dostrzec też u nas można szereg objawów regionalizmu oświatowego polegającego na tworzeniu szkół i instytucji oświatowych realizujących kształcenie w oparciu o wartości kultury oraz inne treści programowe czerpane $\mathrm{z}$ regionu. W latach międzywojennych jego egzemplifikacją był, zainicjowany przez Aleksandra Patkowskiego, Powszechny Uniwersytet Regionalny. Do tych tradycji nawiązuje w pewnym stopniu współczesna Wszechnica Roztoczańska (Kaczor, 2002) w Szczebrzeszynie, Uniwersytet Powszechny w Teremiskach oraz dynamiczny dzisiaj ruch uniwersytetów III wieku organizujący m.in. zajęcia o treści regionalnej oraz inicjujący różne akcje aktywizacji kulturalnej i edukacyjnej w środowiskach lokalnych. Odrębnym zagadnieniem kulturowym i edukacyjnym czasów współczesnych jest powstanie w naszym kraju dużej liczby rozgłośni radiowych i stacji telewizyjnych typu regionalnego oraz lokalnego, sięgających przy tworzeniu repertuaru do dorobku kulturalnego i wartości własnego regionu oraz edukujących przez swe programy nie tylko regionalnych odbiorców.

Elementem bardzo już dojrzałego, by nie powiedzieć zaawansowanego, regionalizmu naukowego (lub występującego w nauce) w naszym kraju jest pojawienie się sporej liczby zwartych publikacji rozmaitego rodzaju, których treścią są sprawy poszczególnych regionów, niezależnie od miejsca, gdzie publikacje te powstały. Podsumowują one i na ogół integrują wiedzę o różnych zjawiskach regionalnych i lokalnych, niekiedy rozproszoną po róż- 
nych publikacjach. Przez to umożliwiają podjęcie zainteresowanym osobom gruntownych studiów nad dziejami oraz współczesnością regionów i rozmaitych miejscowości. Z powodu ogromnej ilości zamieszczonych w nich informacji (a więc nie tylko z przyczyn sporej objętości, jeśli idzie o ilość stron) świadczących o ogromnym nakładzie pracy włożonym przez autorów w ich przygotowanie nazywać je można umownie „pomnikowymi dziełami regionalizmu".

Pierwszym rodzajem tych publikacji są bibliografie regionalne i lokalne. Są one uporządkowanym, według przyjętych kryteriów, spisem (wykazem) prac („dokumentów”) o danym regionie (niezależnie od miejsca ich powstania i pochodzenia ich autorów). Rejestrują one książki, czasopisma, artykuły prasowe, mapy, plany informatory, katalogi (np. wystaw), programy imprez, pamiętniki i dokumenty życia społecznego oraz inne dotyczące poszczególnych regionów i miejscowości. Dzisiaj w naszym kraju mamy kilka imponujących, opracowywanych przez wiele lat, tego typu bibliografii. Przykładem jest Bibliografia Warszawy wydawana od 1958 roku, początkowo przez Muzeum Historyczne m. st. Warszawy (7 tomów) a następnie (od 1996) przez Bibliotekę Publiczną m. st. Warszawy jako Bibliografia Warszawy i Województwa Warszawskiego (red. Jolanta Błaszczyk). W każdym jej tomie zarejestrowanych bywa, co roku, do 10 tys. druków („dokumentów”). Monumentalna jest Bibliografia regionalna Wielkopolski zainicjowana w 1959 roku (jako wydawnictwo) przez Bibliotekę Główną Uniwersytetu Adama Mickiewicza i kontynuowana (od 1980 roku) przez Wojewódzką Bibliotekę Publiczną w Poznaniu i (od 1986 roku) przez Centrum Animacji Kultury w Poznaniu. Działając w takiej kooperacji, wymienione instytucje do tej pory wydrukowały blisko 100 tomów (zeszytów) Bibliografii regionalnej Wielkopolski. W zbliżonych warunkach powstawała, tworzona od 1963 roku przez Śląski Instytut Naukowy, a następnie przez Bibliotekę Śląską w Katowicach, wielotomowa Bibliografia Śląska. Do dużych regionalnych bibliografii należą też: Bibliografia Pomorza Zachodniego, wydawana przez Książnicę Pomorską w Szczecinie, rejestrująca od 1962 roku druki dotyczące regionu szczecińskiego i koszalińskiego, Bibliografia Warmii i Mazur wydawana od 1964 roku przez Wojewódzką i Miejską Bibliotekę Publiczną w Olsztynie, a także zainicjowana już w 1944 roku Bibliografia Rzeszowszczyzny (od 1975 roku Bibliografia województw: krośnieńskiego, przemyskiego, rzeszowskiego i tarnobrzeskiego) - licząca (do 2010 roku) 94 tomy sporej wielkości. Moda na rejestrowanie dorobku naukowego i artystycznego w postaci spisów publikacji objęła u nas także mniejsze geograficznie regiony, a nawet pojedyncze mniejsze miejscowości. Efektem jest kilkutomowa (nie pierwsza, bo były 
wcześniejsze) Bibliografia powiatu sądeckiego opracowywana od lat w Sądeckiej Bibliotece Publicznej (Marta Treit i in.), Marii Sąsiadowicz Bibliografia miasta Tarnowa (9 tomów), Bibliografia Tarnobrzega tworzona w Miejskiej Bibliotece Publicznej w Tarnobrzegu (tylko wydanie za 2012 rok rejestruje 6436 druki dotyczące Tarnobrzega i okolicy uporządkowanych w 15 działach) oraz inne.

Ruch rejestrowania dorobku pisarskiego dotyczącego poszczególnych regionów dowodzi wielkiej pracowitości i swoistej determinacji twórców poszczególnych bibliografii. Pokazuje też, jak praca nad rejestrowaniem niekiedy pokaźnego dorobku pisarskiego integruje zgodnie pracujących autorów (zbiorowych) bibliografii regionalnych w obrębie lokalnych bibliotek, muzeów i innych instytucji kultury poszczególnych regionów. Wydawanie tych bibliografii to sprawdzony sposób nobilitacji poszczególnych regionów i miejscowości. Tworzone i stale uzupełniane bibliografie regionalne to doskonałe narzędzie pracy nie tylko dla kolejnych regionalistów, ale także niemal pewna informacja o rozległych źródłach wiedzy o regionie dla uczącej się młodzieży i kształcących się ludzi dorosłych.

Widząc korzyści z regionalnej i lokalnej bibliografistyki, należałoby sobie życzyć, aby ruch tworzenia lokalnych bibliografii objął także środowiska geograficznie mniejsze, w postaci gmin, a nawet poszczególnych sołectw. Trzeba przyznać, że zamiar i potrzeba opracowywania bibliografii małych środowisk lokalnych wyzwalają w wielu miejscowościach naszego kraju sporą aktywność intelektualną pracowników bibliotek miejskich i gminnych oraz lokalnych miłośników regionu w postaci wszczęcia poszukiwania i rejestrowania dokumentów pisanych, dotyczących ich miejscowości. Dzięki niej nadal powstają kolejne (nie zawsze drukowane) regionalne i lokalne spisy publikacji dotyczące miasteczek i wsi.

Drugą formą współczesnego regionalizmu polskiego stało się wydawanie lokalnych czasopism. Trudno byłoby dzisiaj znaleźć w kraju powiat czy nawet gminę, w których nie drukuje się jakiegoś periodyku. Niektóre z tych wydawnictw mają już poważny dorobek naukowy i popularyzatorski. Przykładem są: „Rocznik Gdański”, „Rocznik Sądecki”, Rocznik Przemyski”, „Rocznik Toruński” „Kutnowskie Zeszyty Regionalne”, „Prace Pienińskie”. Wydawcami są najczęściej regionalne stowarzyszenia naukowe, towarzystwa przyjaciół regionu, samorządy miast i instytucje kultury. Coraz częściej własne pisma, przeważnie w postaci miesięczników i tygodników oraz okazjonalnych jednodniówek, wydają dzisiaj samorządy powiatów i gmin, lokalne zakłady pracy, instytucje kultury (np. muzea regionalne, biblioteki), parafie i szkoły średnie (uczelnie wyższe czynią to w zasadzie „obowiązkowo”). 
Niektóre z nich mają już spory dorobek w postaci popularności i dużej liczby czytelników. Przykładem takich pism są: „Tygodnik Podhalański” wydawany w Nowym Targu od 25 lat czy niewiele późniejszy (tygodnik) „Almanach Sądecki”. Działalność tej prasy wspiera (ogólnopolskie) Stowarzyszenie Prasy Lokalnej. Często utrzymują się wyłącznie z zamieszczanych reklam, ale faktem jest, że inicjują różne ważne społecznie lokalne akcje (np. porządkowania miejscowości, poprawy ich stanu sanitarnego oraz estetyki, piętnowania lokalnej korupcji i nepotyzmu) na rzecz rozwoju własnych miejscowości. Przygotowywanie, redagowanie, a następnie dystrybucja oraz czytanie tych pism to intensywny, niekiedy pełen pasji proces edukacyjny i to nie tylko dla osób w jakimś stopniu związanych z miejscowościami, których dotyczy ich treść.

Zdaje się, że najwyższą formą regionalizmu jako ruchu naukowego jest opracowywanie i wydawanie encyklopedii (regionalnych) poszczególnych miejscowości (i okolic). Do tej pory w naszym kraju opracowanych zostało kilkanaście takich (by nie wymieniać małych) encyklopedii. Pierwszą jest monumentalna Encyklopedia Warszawy (1994, około 7 tys. haseł, ss. 1071). Drugą i do tej pory największą - Zofii i Witolda Paryskich - Encyklopedia Tatrzańska (1995, około 5,8 tys. haseł, ss. 1553). Następną - wyliczając chronologicznie - Encyklopedia Krakowa (2000, prawie 5,5 tys. haseł, ss. 1136). Do nich wnet dołączyły: Encyklopedia Rzeszowa opracowana pod redakcją Jana Krausa (Rzeszów 2004, ss. 839) w pewnym stopniu uzupełniona przez dzieło Władysław Henninga Rzeszowski Alfabet miejsc często już zapomnianych i osób z nim zwiq̨zanych (Rzeszów 2012, Podkarpacki Instytut Książki i Marketingu), Encyklopedia Wrocławia przygotowana pod red. Jana Harasimowicza (Wrocław 2006 ss. 1060), Encyklopedia Gdyni (Gdynia 2006, ss. 999), Jerzego Zysnarskiego - Encyklopedia Gorzowa (Gorzów 2007, ss. 767), Encyklopedia Gniezna i Ziemi Gnieźnieńskiej firmowana przez Towarzystwo Miłośników Gniezna (Gniezno 2011, ss. 772), Andrzeja Kędziory Encyklopedia miasta Zamościa (Zamość 2012, wydanie drugie po 11 latach od pierwszego, ss. 833). Ten zbiór powiększony został w 2012 roku o kolejne monumentalne (około 7,1 tys. haseł, ss. 1174) i - co trzeba powiedzieć wspaniałe dzieło, jakim jest Encyklopedia Gdańska (Gdańsk 2012). Niezwykłość pod względem merytorycznym, naukowym i upowszechnieniowym, a także edytorskim dzieła zapowiada uwidoczniony na jego wstępie Komitet Honorowy Encyklopedii, któremu przewodniczył Prezydent Rzeczypospolitej Polskiej - Bronisław Komorowski. W 2013 roku ukazał się I tom (tworzony przez dwa odrębne woluminy) zakrojonej na wiele części Encyklopedii Chet$m a$, a przygotowywanej przy współpracy profesorów i innych nauczycieli 
akademickich Państwowej Wyższej Szkoły Zawodowej działającej w tym mieście.

O tym, jak modnym stał się dziś ruch opracowywania encyklopedii poszczególnych miast i regionów, dowodzi pojawienie się na Śląsku (Wydawnictwo Prasa i Książka Grzegorza Grzegorka) serii wydawniczej Małych Encyklopedii Małych Ojczyzn. W jej ramach do tej pory ukazały się Encyklopedia Chorzowa (edycja 2009, ss. 624) i Encyklopedia Powiatu Bieruńsko-Lędzińskiego (2010, ss. 655).

Przygotowywanie i druk dużych objętościowo encyklopedii miast i regionów jest u nas kontynuowany. Wspomniane zaś Wydawnictwo Prasa i Książka zamierza wydać w najbliższych latach, w ramach wymienionej serii, encyklopedie 14 miast (i niektórych powiatów) Górnego Śląska. Już w przygotowaniu są encyklopedie: Katowic, Piekar Śląskich, Rudy Śląskiej i in.

Oryginalną formę współczesnego regionalizmu stanowi redagowanie i wydawanie monografii (z reguły historycznych) wielu miejscowości. Początek temu nurtowi twórczości naukowej dały Mariana M. Drozdowskiego i Andrzeja Zahorskiego Historia Warszawy (PWN 1972, wyd. IV, 2004) oraz Dzieje Krakowa (red. J. Bieniarzówna i J. M. Małecki, t. I, 1992). „Moda” na dokumentowanie swych dziejów nie jest jedynie wytworem wielkich miast. Wnet „zeszła” ona na miasta średniej wielkości (a ruch ten od kilku lat charakteryzuje się dużą dynamiką). Jego efektem są następne, z reguły duże, monografie. Przykładem są m.in. (3-tomowe) monografie: Tarnów. Dzieje miasta i regionu (1981-1983), Mielec. Dzieje miasta i regionu (1984-1994), Dzieje miasta Nowego Sq̨cza (1992-1996), a następnie Dzieje Olkusza i regionu olkuskiego (red. Feliks Kiryk, 1978), Monografia Zawiercia (red. Zdzisław Jagodziński, 2003) i in.

Z czasem owa „moda” opanowała również miasteczka. W jej efekcie monografii historycznych doczekały się: Bochnia (Bochnia: dzieje miasta i regionu, (1980)), Stary Sącz (Historia Starego Sącza, t. 1 - 1979, t. 2 - 1995), Limanowa (Limanowa. Dzieje miasta, t. 1 - 1999, t. 2 - 2002), Trzebinia (Trzebinia. Zarys dziejów miasta i regionu, 1994) Ożarów (Ożarów. Dzieje miasta i gminy, 2009) i in.

Ostatnim krzykiem naukowej „mody” wśród regionalistów staje się także pisanie obszernych (zbiorowych) monografii historycznych wsi i gmin wiejskich. Piszemy o „zbiorowych”, ponieważ monografie tworzone przez pojedynczych autorów, pasjonatów lokalnych badań, pojawiły się w naszym kraju dawno. Przykładem są prace Franciszka Bujaka Maszkienice - wieś powiatu brzeskiego. Stosunki gospodarcze i społeczne (1901) i Żmiq̨ca - wieś powiatu limanowskiego. Stosunki gospodarczo-społeczne (1903), Wincentego 
Stysia - Drogi postępu gospodarczego wsi (1947), Franciszka Mleczki - Wieś rodzinna wzywa (1963), Małgorzaty Kiereś Istebna. Zarys dziejów beskidzkiej wsi (2014) i wiele innych.

Początek zbiorowym monografiom gmin wiejskich daje publikacja pt. Czarny Dunajec i okolice. Zarys dziejów do roku 1945 (red. F. Kiryk, 1997). W pewnym stopniu kontynuację tego nurtu piśmiennictwa naukowego stanowi monumentalne dzieło zbiorowe pt. Eq̨cko i gmina łq̨cka opracowane pod redakcją Juliana Dybca, opublikowane w 2012 roku przez Oficynę Wydawniczo-Drukarską SECESJA z Krakowa, a także drukowana w tej chwili obszerna monografia (red. F. Kiryk) gminy Podegrodzie (koło Starego Sącza).

Do pomników regionalizmu polskiego zaliczyć trzeba dynamicznie rozwijającą się u nas w ostatnich dziesiątkach lat biografistykę (regionalną i lokalną). Efektem tego ruchu jest powstanie całej serii regionalnych słowników biograficznych i im podobnych wydawnictw zawierających życiorysy osób zasłużonych, żyjących i pracujących w danym regionie (miejscowości) lub wywodzących się z niego. Publikacji tych jest u nas już wiele i stale powiększa się ich liczba. Cechuje je także rozmaity zasięg od słowników rozległego geograficznie („szerokiego”) regionu do publikacji lokalnych (miejscowych) zawierających życiorysy i opis działalności osób związanych z jedną konkretną miejscowością czy nawet jej częścią (np. ks. Jana Góreckiego Nowy Bytom i jego mieszkańcy sprzed lat). Mają też różne tytuły. Nie zawsze informujące, że to klasyczny słownik biograficzny. Przeważnie zawierają życiorysy wszystkich uznanych za znaczące w danym regionie osób. Inne poświęcone zostały zobrazowaniu życia i działalności ludzi wybranego zawodu lub grupy zawodów.

Jedne $\mathrm{z}$ tych publikacji są dziełem zbiorowym wielu ludzi, inne opracowane zostały przez pojedynczych pasjonatów badań regionalnych i regionalnej biografistyki. Przykładem pierwszym jest imponujący rozmiarami Słownik biograficzny Pomorza Nadwiślańskiego wydany w 6 tomach i 3 uzupełniających te tomy książkowych suplementach w latach od 1992 (tom 1) do 2012 (suplement III) przez Gdańskie Wydawnictwo. Każdy tom przygotowywany był przez kilkudziesięciu autorów pracujących początkowo pod kierownictwem (redakcją) Stanisława Gierszewskiego (1929-1993), a następnie Zbigniewa Nowaka. W pierwszych 6 tomach opublikowane zostały 2154 biogramy ludzi zasłużonych, związanych urodzeniem i działalnością z Pomorzem Nadwiślańskim. Słownik opracowywany był w ciągu 25 lat przez 314 autorów. W trzytomowym suplemencie zamieszczonych zostało 978 życiorysów następnych osób. Życiorysy dla potrzeb suplementu opracowywało prawie 200 autorów. 
Równie obszerny jest Włocławski słownik biograficzny opracowywany pod egidą Włocławskiego Towarzystwa Naukowego od 2003 roku, pod redakcją Stanisława Kunikowskiego. W latach 2004-2011 ukazało się 6 tomów tego Słownika zawierających około 700 życiorysów zasłużonych ludzi z Ziemi Włocławskiej: opracowanych przez ponad 200 autorów. Imponuje też wielkością (ss. 1245) Stanisława Pajki Słownik biograficzny Kurpiowszczyzny XX wieku (Kadzidło, 2008) zawierający dokładnie 2001 biogramów (i 1916 zdjęć) ludzi zasłużonych z obszarów Puszczy Białej i Puszczy Zielonej oraz terenów do nich przyległych, a także Tadeusza Stolarskiego - nauczyciela i regionalisty dyrektora szkoły z Włoszczowej - pt. Znani i Nieznani Ziemi Jędrzejowskiej - dzieło dwutomowe (ss. 1550), zawierające szczegółowe i obszerne życiorysy 446 osób związanych z wymienionym regionem. Obszerną (ss. 699) jest także publikacja pt. Wielkopolanie XX wieku zawierająca sporej wielkości życiorysy (w tym i mało znanych, a niezwykle interesujących informacji biograficznych) wybitnych ludzi tego wieku związanych z Wielkopolską, począwszy od ks. bpa Stanisława Adamskiego (1875-1967), a na Florianie Znanieckim (1882-1958) skończywszy.

Przykładem prac zbiorowych dotyczących pojedynczych miejscowości jest w pierwszym rzędzie obszerny Toruński słownik biograficzny publikowany w latach 1997-2014 w siedmiu kolejnych tomach. Wydawnictwo zainicjowane i wydawane pod redakcją Krzysztofa Mikulskiego, sumptem Towarzystwa Miłośników Torunia. Do godnych uwagi należy też obszerny, 2-tomowy Chorzowski słownik biograficzny (edycja nowa, powiększona, po wyczerpaniu pierwszej z 1997 roku) opracowany pod redakcja Zbigniewa Kapały, wydrukowany dzięki wsparciu Muzeum w Chorzowie. W obszernym (ss. 480) pierwszym tomie zamieszczone zostały życiorysy wybitniejszych chorzowian sprzed 1922 roku (włączenie Śląska, po plebiscycie, do Macierzy). Natomiast tom drugi (ss. 530) zawiera życiorysy chorzowian zasłużonych dla miasta i kraju z lat 1922-1945. Wydawca zapowiedział przygotowanie trzeciego tomu Słownika.

Przykładu prac omawianego typu opracowanych przez jednego autora dostarcza Czesława Olejnika 2-częściowy (ss. 759) Wolsztyński słownik biograficzny zawierający ponad 200 życiorysów ludzi związanych z Ziemią Wolsztyńską, którzy wyróżnili się na niwie zawodowej, publicznej i społecznej. Dzieło wydrukowane zostało staraniem pracowników Biblioteki Miasta i Gminy Wolsztyn (część II w 2007 roku). Podobnym wydawnictwem jest praca ks. Ryszarda Tuzina, poety i publicysty oraz badacza przeszłości swojej parafii i okolicznych wsi, pt. Błaszkowianie (Łódź 2010). Zawiera ona opis życia i działalności 100 ludzi urodzonych w miasteczku Błaszki (koło Siera- 
dza) w XX wieku, a zasłużonych nie tylko dla rozwoju tej miejscowości. Zaletą tej pięknie ilustrowanej publikacji jest szczegółowa charakterystyka jej życia społecznego oraz opis przemian oświaty i kultury w Błaszkach. Podobną pracę wykonał ks. Jan Górecki (od 1983 roku proboszcz parafii nowobytomskiej w Rudzie Śląskiej), opracowując - wspomnianą już - obszerną (ss. 447) publikację Nowy Bytom i jego mieszkańcy, wydaną własnym sumptem (Nowa Ruda 2001). Zawiera ona, poza opisem dziejów Nowego Bytomia i przeszłości miejscowej parafii, szczegółowe życiorysy 71 ludzi tworzących historię nowobytomską, a zarazem zasłużonych dla miejscowej parafii, ludzi - jak określił sam Autor - żyjących „[...] dla rodziny, parafii i zakładu pracy [...]. Znaczącym zaś wydarzeniem wydawniczym 2012 roku, w skali Nowego Sącza i Sądecczyzny, było ukazanie się wartościowego i bogato ilustrowanego dzieła Jerzego Leśniaka - miejscowego zasłużonego redaktora i wybitnego regionalisty - zatytułowanego 101 sq̨deczan (ss. 323). Publikacja przygotowana została dla uczczenia (przypadającej na 2012 rok) 720 rocznicy założenia Nowego Sącza przez króla czeskiego Wacława II. Po jej ukazaniu się autor przedłożył wykaz kolejnej setki zasłużonych dla kraju sądeczan $\mathrm{z}$ intencją rychłego napisania ich biogramów.

Odmianą omawianych słowników biograficznych, zarówno regionalnych, jak i lokalnych, są publikacje zawierające życiorysy osób określonej kategorii społecznej i zawodowej. Do pierwszych należą np. słowniki biograficzne ziemian żyjących na określonym terytorium. Do drugich - publikacje zawierające życiorysy przedstawicieli różnych kategorii zawodowych. Do pierwszego z tych typów publikacji należą np. Rody. Rodziny Mazowsza i Podlasia. Źródła do badań genealogicznych (pod red. Doroty K. Rombiszewskiej i Haliny Krajewskiej) wydane w 2013 roku przez Łomżyńskie Towarzystwo Naukowe im. Wagów. Publikacje tego rodzaju - mimo że nie zostały zatytułowane jako „słowniki” - zawierają różnej wielkości życiorysy osób zasłużonych w danej dziedzinie działalności zawodowej i społecznej. Przykładem drugich - opracowany pod redakcją dwu rzeszowskich profesorów, Andrzeja Meissnera i Kazimierza Szmyda - Słownik biograficzny twórców oświaty i kultury XIX i XX wieku Polski Południowo-Wschodniej (Rzeszów 2011). Zawiera on (ss. 498) około 700 biogramów osób następujących kategorii: animatorów życia kulturalnego, profesjonalnych i „ludowych" twórców oraz odtwórców kultury, dziennikarzy, wydawców, bibliotekarzy, drukarzy, pisarzy, pamiętnikarzy, malarzy, rzeźbiarzy, muzyków, kompozytorów, muzealników, archiwistów, etnografów, twórców fotografii artystycznej i in. W ostatnich latach pojawiają się u nas słowniki biograficzne osób poległych i pomordowanych, zwłaszcza na Wschodzie. Przykładem publikacja pt. Katyń, Char- 
ków, Twer. Chełmskie ofiary zbrodni sowieckich (opr. Janusz P. Krzywicki i Zbigniew S. Lubaszewski, Chełm 2013) zawierająca noty biograficzne około 220 oficerów zamordowanych na Wschodzie, związanych (urodzeniem lub pracą z Chełmem i Ziemią Chełmską). Identyczny charakter ma Jerzego Gizy - Nowosądecka lista katyńska. Pomordowani w Rosji Sowieckiej (Nowy Sącz 2009). Autor zamieścił w niej biogramy 224 ofiar sowieckiej zbrodni związanych pochodzeniem lub wykonywaną pracą z Ziemią Sądecką.

W ostatnich dziesiątkach lat pojawiać się też zaczęły w naszym kraju słowniki biograficzne ziem kresowych, oderwanych w wyniku II wojny światowej od Polski. Początek dał im Wileński słownik biograficzny opracowany pod egidą Miłośników Wilna i Ziemi Wileńskiej, mający już dwa wydania (drugie: Bydgoszcz 2008) zawierający ponad 1400 biogramów ludzi zasłużonych z Ziemi Wileńskiej. Jego uzupełnieniem jest sporej wielkości (ss. 331) Suplement (Bydgoszcz 2012). Do tego typu publikacji należą także: Władysława Szklarza - Życiorysy Buczaczan (Wrocław 2007) opublikowane w ramach prac Towarzystwa Miłośników Lwowa i Kresów Południowo-Wschodnich. Autor, prowadząc przez kilka lat żmudne i trudne badania historyczne (m.in. penetracja epitafiów na 34 cmentarzyskach), na 660 stronach swego dzieła zamieścił życiorysy 10227 osób narodowości polskiej urodzonych i działających w przeszłości na Ziemi Buczackiej. Zaletą publikacji jest to, że życiorysy te poprzedzone są interesująco napisanymi dziejami Polaków (łącznie z dramatycznymi ich losami w czasie II wojny światowej) na interesującym autora terenie. Podobny charakter ma monumentalna publikacja (6 tomów, wielkości A-3, liczących od 783 (II) do 1119 (VI) stron każdy) ks. Waldemara W. Żurka pt. Wykazy osób z akt parafialnych diecezji łuckiej do 1945 r. (Wydawnictwo „Jedność”, Lublin 2004-2010) zawierająca nie tylko imię i nazwisko czy rok urodzenia wiernych w poszczególnych parafiach, ale i także informacje o zawodzie, pracy i losach życiowych osób odnotowanych.

Innym rodzajem piśmiennictwa regionalnego są (regionalne) przewodniki i informatory turystyczne. Przez zamieszczone w nich szczegółowe treści na temat specyfiki i osobliwości poszczególnych regionów oraz miejscowości stwarzają ogromne możliwości poznania wielu środowisk lokalnych W skali światowej ruch drukowania przewodników po różnych krajach rozpoczął w 1838 roku niemiecki wydawca Karl Baedeker (1801-1859). Dzisiaj jego kontynuatorem w skali świata jest „Pascal”, a w Polsce czyni to m. in. krakowskie Wydawnictwo „Bezdroża”. Wydawcami przewodników krajowych są różne instytucje. Ich aktywność sprawia, że przewodników turystycznych regionalnych i miejscowych mamy coraz więcej Stanowią one źródła usystematyzowanych, szczegółowych informacji o określonych regio- 
nach i miejscowościach, których dotyczą. Wiele z nich (stale poprawianych, rozszerzanych i uzupełnianych) w ostatnich latach, obok opisywania zalet w postaci osobliwości turystycznych, ukazuje także rozbudowę ich infrastruktury usługowej i specyfikę gospodarczą (np. Bukowina Tatrzańska, Kraków 2002). O tych licznych wydawnictwach informuje Bibliografia turystyki oraz bedekery (np. Bedeker Tatrzański pod red. Ryszarda Jakubowskiego (2000) czy Tadeusza Bolduana Nowy Bedeker Kaszubski (2002)). Są one niejednokrotnie „kopalnią” wiedzy o poszczególnych regionach i miejscowościach, a także żyjących tam ludziach. Stąd ich duże dydaktyczne zalety. Są bowiem przydatne jako niezastąpione źródło wiedzy w edukacji instytucjonalnej i samokształceniu.

Ważny element polskiego regionalizmu naukowego stanowią prace o charakterze monograficznym. Traktują one o różnych zjawiskach o zasięgu regionalnym: języku (w tym i gwarze), zwyczajach (np. bożonarodzeniowych), obyczajach, sposobach i organizacji pracy, technice i procesie wyrobu przedmiotów regionalnych, budownictwie, świętowaniu, historii, szkolnictwie, kulturze, sztuce i folklorze, stroju, muzyce, świętowaniu i in. Przykładem prac dawniejszych jest kilkakrotnie wydawana Tadeusza Dobrowolskiego Sztuka Krakowa (wydanie V, 1978, ss. 664) ukazująca dawne (preromanizm, romanizm, gotyk, renesans, manieryzm, barok i in.) i współczesne (architektura, rzeźba, malarstwo i rzemiosło artystyczne) zjawiska artystyczne tego miasta. Natomiast do publikacji tego typu niemal z ostatniej chwili należy monumentalne dzieło Marzeny Raińskiej Dwory Małopolski. Historia i wspótczesność (2014). To przepięknie ilustrowane, 3-tomowe dzieło (ss. 1151, format A-3) ukazuje: przeszłość, aktualny stan techniczny pałaców, dworów i dworków w poszczególnych powiatach Małopolski oraz elementy życia codziennego dawnych właścicieli i współczesnych użytkowników tych obiektów.

Następną kategorię „pomnikowych” dzieł regionalizmu polskiego stanowią wydawnictwa albumowe (o treści regionalnej i lokalnej). Są to z reguły książki, wydawane w bardzo starannej szacie graficznej, niemal luksusowo, zawierające głównie ilustracje, fotografie (zabytków, miast, parków, krajobrazu i innych urokliwych zakątków), widoki, pejzaże reprodukcje dzieł malarskich, rysunki, grafiki i in. z tekstem słownym zredukowanym do koniecznego minimum. W związku z tym szerzą one wiedzę o świecie, człowieku i jego dziełach za pomocą obrazu, a jednocześnie obcowanie z nimi ze względu na wartości artystyczne zamieszczonych jest doskonałą formą wychowania estetycznego. Wydawnictwa te na ziemiach polskich zainicjował Jan Feliks Piwowarski (1794-1859) - znany rysownik, grafik, wydawca, 
profesor malarstwa w warszawskiej Szkole Sztuk Pięknych, redagując (redaktor artystyczny) nowocześnie (wtedy) wydany album pt. Monumenta Requm Poloniae Cracoviensia. Ważną kontynuacją (II połowa XIX wieku) jego idei było wydawnictwo (pięć serii wydawniczych) Album wileńskie (Album de Vilna) Jana Kazimierza Wilczyńskiego (1806-1885) - wileńskiego lekarza i kolekcjonera o wszechstronnych zainteresowaniach. Dzisiaj w naszym kraju albumów wydaje się bardzo dużo. Interesując się tylko tymi o treści regionalnej, łatwo ze względu na treść podzielić je na cztery kategorie: ukazujące piękno poszczególnych zabytków (w tym także przyrody), ilustrujące urok określonych miast i osobliwości wybranych regionów, a także dokumentujące przebieg różnego typu uroczyści regionalnych.

Przykładem pierwszych jest Jana Samka (prof. UJ) Kościót Mariacki w Krakowie (1990) zawierający 206 wysokiej jakości ilustracji zaopatrzonych w niezbędny komentarz do każdej z nich. Podobną publikacją jest album Sylwestra Adamczyka - absolwenta Wyższej Szkoły Biznesu w Nowym Sączu pt. Sq̨decka Góra Tabor (2006) ukazujący piękno nowosądeckiej Bazyliki św. Małgorzaty i podniosły nastrój urządzanej w niej uroczystości kościelnych. Do omawianego typu należy też album Mariusza Wideryńskiego - geologa i ratownika górskiego, pasjonata fotografii Zamek w Eańcucie (1998) wydany w serii „Rezydencje polskie”, ukazujący piękno i niepowtarzalny nastrój tego obiektu. $Z$ nowszych, publikacji tego typu wymienić trzeba: przepiękny album Jerzego Żaka (zdjęcia) i Andrzeja Piecucha (tekst) pt. Łemkowskie cerkwie (2011), ukazujący urok tych pięknych obiektów, piękno ich otoczenia oraz podniosły nastrój odbywających się w nich uroczystości religijnych.

Obfity jest w naszym kraju ostatnich lat „wysyp” albumów ukazujących piękno poszczególnych, zresztą stale upiększanych miast. W jakimś stopniu początek dają im Dobiesława Kobielskiego - Widoki dawnej Warszawy (1984), ukazując różne piękne fragmenty stolicy przed ich wojennym zniszczeniem. Do podobnych publikacji zaliczyć trzeba, powstały w następstwie zbiorowego wysiłku kilku fotografów i wydawców, album fotograficzny Konin (2000) ukazujący główne budynki tego miasta, urok otaczającej je przyrody oraz oryginalność organizowanych w mieście imprez. Tutaj można jeszcze przypomnieć podobne dzieło wymienionego już artysty fotografika Jerzego Żaka - Krynica-Zdrój. Miasto, ludzie, okolice (2002). Zawiera ono zdjęcia pejzaży, sanatoriów, pensjonatów, will, pijalni, pomników i fontann krynickich, fotografie obiektów sportowych i tras turystycznych, a także ludzi wybitnych odwiedzających Krynicę-Zdrój. Identyczny charakter ma album Radom (2010) powstały z profesjonalnych fotografii Wojciecha Stana znanego miejscowego fotografika i historyka sztuki. Przykładem takich 
dzieł jest także opublikowany w 2012 roku staraniem Muzeum Okręgowego w Nowym Sączu oryginalny w treści i formie album pt. Ikonografia Starego i Nowego Sq̨za. Dzieło stanowi efekt wieloletnich poszukiwań zrealizowanych przez pracowników tej instytucji i ukazuje w sposób niemal wzorcowy rozwój do zabudowy przestrzennej i architektury obu wymienionych miast w oparciu o reprodukowane w nim malarstwo, rysunek, grafikę, obrazy rzeźby $i$ in.

Godna uwagi jest także trzecia grupa albumów. Są nimi publikacje obejmujące szerszy zasięg terytorialny niż pojedyncze miasta czy miastecka, np. określone pasmo górskie, tereny rzeczne i leśne, regiony fizjograficzne. Przykładem i tym razem Jerzego Żaka Beskid Sadecki (1997), Krynica i okolice (1992), Anny Olej-Kobus i Krzysztofa Kobusa album pt. Pomorze (2007) ukazujący piękno zabytków architektury i osobliwości przyrodniczych na terytorium od Szczecina po Elbląg i od Torunia po Władysławowo. Jest on wyraźną konkurencją dla pięknego albumu autorstwa Anny i Włodzimierza Bilińskich Pomorze Zachodnie (1999) ukazującego najcenniejsze poznawczo zakątki wymienionej części Pomorza.

Jako ostatnią kategorię albumów o tematyce regionalnej należy wyróżnić te, które dokumentują przebieg różnego typu uroczystości regionalnych. Są to publikacje ukazujące przebieg w różnych miejscowościach uroczystości weselnych i pogrzebowych, dożynkowych i bożonarodzeniowych, a także artystycznych. Przykładem tych ostatnich jest Festiwal Kapel i Śpiewaków Ludowych w Kazimierzu Dolnym (pod red. Elżbiety Sendejewicz, Lublin 1989) dokumentujący przebieg i rozrastanie się tej imprezy w latach 1967-1987. Dzięki dużej liczbie reprodukowanych zdjęć i ich opisowi ten sporej wielkości (ss. 360) album jest swego rodzaju ilustrowaną encyklopedią polskiego folkloru i jego regionalnego zróżnicowania.

Bogata jest $u$ nas literatura regionalna typu monograficznego traktująca o nekropoliach. Początek okazalszym dziełom z tego zakresu dał Kazimierz Wł. Wójcicki (1807-1879) - warszawski historyk i folklorysta, znany publicysta i edytor. Opracował on 3-tomowe dzieło pt. Cmentarz Powazkowski... wydane w latach 1855-1858 w drukarni S. Orgelbranda. Publikacja ta, jeszcze bez zdjęć, ale z rysunkami, zawiera biogramy spoczywających na tej warszawskiej nekropolii. Niemal pół wieku po tym pojawiły się pierwsze przewodniki po nekropoliach Krakowa (Stanisław Cyrankiewicz Książkowy przewodnik po cmentarzach Krakowa, Podgórza i Zwierzyńca, 1910) i Lwowa (Marek Münz Cmentarz Łyczakowski we Lwowie, 1925) i in.

Renesans tego typu pracy badawczej i pisarstwa naukowego przypadł na koniec lat 70. i lata 80. XX wieku. Wtedy to pojawiła się m.in. publikacja 
Stanisława Szańca Cmentarz Powązowski. Zmarli i ich rodziny (1979-1983, t. I-III); Eugeniusza Szulca - Cmentarz Ewangelicko-Augsburski w Warszawie (1988, t. I-II); Stanisława Sławomira Nicieji - Cmentarz Eyczakowski we Lwowie (1786 - 1986) (1988 oraz dwa następne wydania) i in. Na przełomie wieków XX i XXI pojawiły się kolejne znane przewodniki i monografie nekropolii. Przykładem Mieczysława Jackiewicza Wileńska Rossa. Przewodnik po cmentarzu (1993), wspomnianego Stanisława Sławomira Nicieji Łyczaków. Dzielnica za Styksem (1998), Cmentarz Rakowicki w Krakowie (2003, t. I-III) i wiele innych.

W ostatnich dosłownie latach pojawiają się obszerne monografie nekropolii w mniejszych miejscowościach. Przykładem Marii i Michała Łuczajów Album Pamięci Cmentarza Komunalnego w Krośnie (2007), Piotra Sławińskiego Cmentarz Świętopowelski w Sandomierzu (2010) czy Józefa Tadeusza Sosnowskiego Cmentarz farny w Białymstoku (2012). W ten nurt prac dokumentacyjno-naukowych doskonale wpisuje się publikacja Bogusława Kołcza i Piotra Droździka pt. Nowy Sącz - jeśli zapomnę o nich... (2014) dokumentująca drukiem (biogramy osób spoczywających) i piękną fotografią stan największej sądeckiej Nekropolii, jaką jest tamtejszy Cmentarz Komunalny (1889-2014).

Coraz częściej drukowane też są w naszym kraju informatory o cmentarzach i biogramy osób pogrzebanych za granicą, zwłaszcza na Wschodzie. Przykładem Miednoje. Księga cmentarna Polskiego Cmentarza Wojennego (2006, t. 1-2), monografie cmentarzy wojskowych oraz nekropolii przeznaczonych dla ludzi określonych wyznań.

Wymienione rodzaje i podane przykłady publikacji uznanych za pomnikowe, a zatem imponujące swoją wielkością i naukową (faktograficzną czy dokumentacyjną) wartością dzieła regionalizmu polskiego nasuwają kilka ogólniejszych refleksji. Pierwsza dotyczy autorów i twórców tych dzieł. Pisali je i tworzyli (autorzy zdjęć do albumów) niezwykli miłośnicy, rzec wypada pasjonaci regionu i badań regionalnych oraz dokumentowania (fotograficy) osobliwości regionalnych i lokalnych, zarazem głęboko zainteresowani zagadnieniami, którym poświęcili swoje dzieła. Związani ze swoim regionem urodzeniem (mimo że część z nich mieszka i pracuje poza nim) bądź pracą zawodową (szkoła, biblioteka, muzeum, szkoła wyższa, redakcja miejscowego czasopisma). Cechuje ich doskonałe przygotowanie (merytoryczne i metodologiczne) do badań i dokumentowania osobliwości regionu, które zdobywali nie tylko w czasie kształcenia szkolnego (i akademickiego), ale w toku własnych niejednokrotnie wieloletnich wcześniejszych prac ba- 
dawczych i dokumentacyjnych (fotograficy). Cześć z nich posiada stopnie i tytuły naukowe.

Omówione pomnikowe dzieła regionalizmu polskiego dowodzą ogromnej pracowitości i wytrwałości ich autorów. Tworzyli oni je z dużą determinacją i samozaparciem, z niewyrażalną starannością w toku mozolnego, niekiedy wiele lat trwającego wysiłku. Wykazywali przy tym wiele pomysłowości i pokonywali niekiedy olbrzymie trudności, by odnaleźć, zweryfikować i opracować zebrane, czasem tylko cząstkowe informacje i na ich podstawie odtworzyć losy wielu ludzi (regionalne słowniki biograficzne), wydarzeń i instytucji (encyklopedie regionalne, historia poszczególnych miejscowości), dokonać i ocenić wiele zdjęć, by później móc je zakwalifikować do opublikowania w albumie. Owa determinacja i wytrwałość, a także dobra, efektywna praca dokumentacyjna twórców omówionych dzieł to dobry wzór do naśladowania nie tylko dla następnych badaczy i dokumentalistów, ale i dla innych w zmaganiach z codziennością.

Refleksja druga dotyczy funkcji tych, zazwyczaj monumentalnych, publikacji. Dzięki nim utrwalone zostały z reguły szczegółowo życiorysy wprost niezliczonej ilości osób (w tym także wcześniej prawie zapomnianych) i napisane niekiedy nawet drobiazgowe historie wielu miejscowości, a także utrwalone (albumy, ilustrowane monografie nekropolii) piękno zabytków historycznych i urok ich krajobrazu. Tym samym publikacje te chronią przeszłość regionów i ludzi tam żyjących od zapomnienia.

Omówione dzieła regionalizmu to także powód do dumy dla ludności mieszkającej współcześnie w poszczególnych regionach i środowiskach lokalnych, to sposób na podniesienie u niej poziomu poczucia wartości i znaczenia własnego środowiska (lokalnego i regionalnego), dumy i satysfakcji $\mathrm{z}$ urodzenia się i pracy w danym regionie czy miejscowości. Mówiąc inaczej, to ważny stymulator lokalnej tożsamości, patriotyzmu i szczycenia się swoją Małą Ojczyzną.

Nie można też pominąć funkcji dydaktycznych i wychowawczych omówionych, niekiedy monumentalnych dzieł naukowych i artystycznych (albumy). Są one źródłem rozleglej wiedzy o poszczególnych regionach, miejscowościach i żyjących w nich ludziach oraz geograficznych osobliwościach (albumy). W związku z tym mogą być (o ile to „dostrzegą" nauczyciele i oświatowcy) doskonałą pomocą w nauczaniu szkolnym (dzieci i młodzieży), kształceniu dorosłych w różnych instytucjach, a także w samokształceniu.

Trzeba też powiedzieć, że bez tych dzieł i bez znajomości opisanej w nich przeszłości regionów i miejscowości niemożliwe jest dokładne i szczegółowe poznanie przeszłości naszego kraju. Dopiero poznanie np. 
szczegółowych prac na temat przeszłości Podkarpacia uświadomić może, że rozbiory Polski zaczęły się nie w 1772 roku, a dwa lata wcześniej, bo z chwilą zajęcia (w 1770 roku) przez Austriaków Ziemi Nowotarskiej i Nowosądeckiej. Podobnie jest z szczegółową wiedzą na temat Małopolski u progu odbudowy niepodległości Państwa Polskiego, która odsłania wiele faktów na temat pomocy z jej strony dla kolejnych Powstań Śląskich. Ta sama „regionalna" wiedza pozwoli nam zrozumieć decyzję o dość wczesnym wycofywaniu się we wrześniu 1939 roku ze swoich pozycji niektórych formacji Armii „Kraków” z powodu zagrożenia spowodowanego uderzeniem na nie „z boku”, od południa - oddziałów armii słowackiej, współdziałającej wtedy z opanowującym nasz kraj Wehrmachtem. Takich i im podobnych korzyści, ułatwiających pełniejsze poznanie przeszłości i teraźniejszości naszego kraju, dzięki wiedzy utrwalonej w omówionych pomnikowych dziełach regionalizmu polskiego wskazać można jeszcze bardzo dużo.

\section{Bibliografia}

Brzezińska A. W., Tuchonowicz M. (red.) (2013), Atlas polskich strojów ludowych. Stroje ludowe jako fenomen kultury, Polskie Towarzystwo Ludoznawcze, Wrocław.

Fryś-Pietraszkowa E., Iracka A., Pokropek M. (1998), Sztuka Ludowa w Polsce, Wydawnictwo Arkady, Warszawa.

Kaczor S. (2002), O powstaniu i trzech latach działalności Wszechnicy Roztoczańskiej, Wydawnictwo Instytutu Technologii Eksploatacji, Radom.

Sieraczkiewicz J., Święch J. (1999), Skanseny. Muzea na wolnym powietrzu, Wydawnictwo Bosz s.c., Olszana.

Węglarz S. (1997), Tutejsi i inni. Cz. I. O etnograficznym zróżnicowaniu kultury ludowej, Polskie Towarzystwo Ludoznawcze, Łódź. 
